\title{
Assessing The Organizational READINEss For IMPLEMENTING KNOWLEDGE MANAGEMENT IN ORGANIZATIONS
}

\author{
Sepideh Shahidi, Neda Abdolvand and Saeedeh Rajaee Harandi \\ Department of Management, Alzahra University, Tehran, Iran
}

\begin{abstract}
The growing importance of business analytics and its increasing influence on the competitive advantage of organizations leads to the necessity of knowledge management systems, which complex and needs organizational readiness that has been the subject of earlier research. This study aims to examine whether the affective factors on the assessment of the readiness for implementation of the knowledge management system in all organizations are identical. Hence, first by a comprehensive study of literature, readiness factors of the knowledge management system implementation including six factors of organizational culture, individuals, information technology infrastructure, knowledge process, senior management commitment, and strategy were extracted and have been tested in three different organizations of IT services, educational and commerce. Based on the founding, different factors affect various organizations and using a general model should not be advised.
\end{abstract}

\section{KEYWORDS}

Organizational readiness, knowledge management implementation, IT infrastructure, knowledge process

\section{INTRODUCTION}

Knowledge management (KM) is a structured process of targeting, identifying, acquiring, developing, distributing, applying, measuring, and evaluating the organization's knowledge [2][33][40]. The subjective, portable, latency, self-reinforcement, degradation, and self-motive features of knowledge distinct it from other assets [7]; further, designing and organizing the knowledge make it possible to provide a platform for competition, sustainable development [4] and economic competitive advantages [26]. KM emphasizes on three main areas of individual, structure, and technology and tries to balance threefold working area with production, appropriate use of knowledge resources, and organizational goals [2][33]. The KM implementation includes the extensive domain and different aspects. Hence, without a suitable infrastructure and organizational readiness, the successful implementation of $\mathrm{KM}$ is impossible. Moreover, organizational readiness for KM implementation includes the organizational capability to adopt and use of its advantages. The vast majority of studies on organizational readiness has examined different effective factors; furthermore, research that focused on information technology (IT) and culture showed different results in different organizations. For example, the study of El-Mekawy \& Rusu on the strategic alignment between two branches of the multinational organization in Sweden and Egypt showed different results [10]. 
Culture influences the individuals and organizations' behavior and may lead to different IT systems outcome [20]. IT is known as the effective factor on the IS implementation [22]. The question is that whether the culture and different IT assets influence the effective readiness factors for KMS implementation. Hence, by extracting factors that affect the readiness of three different educational, commercial and IT services organizations, this research aims to study whether a basic model of KM readiness is applicable in various organizations. The results can help the readiness models selection and preparing the infrastructure for KM implementation.

Regarding the purpose, this study begins with a brief literature review. Then, the model is developed by extracting the effective factors of the readiness, followed by a review of the research methodology. The last part of the research includes conclusion and recommendation of study.

\section{LITERATURE REVIEW}

\subsection{Knowledge}

In the 1980s, the Knowledge was introduced by Nonaka as an organizational strategy and gradually was proposed as an organizational capital and strategic management [28][27][32]. Knowledge was used in artificial-intelligence-based systems and intelligent KMS, and the concepts of knowledge acquisition, engineer, and knowledge systems and the like was outspread [9]. Nonaka and Takeuchi defined knowledge as the subjective structure of beliefs, perspectives, meanings, expectations, and methodologies to predict the future outcomes [27]. Knowledge exists within people and is part of the human complexity and unpredictability; transforming data into information and knowledge, is the main issue of $\mathrm{KM}$ [7]. $\mathrm{KM}$ is defined as the systematic management of the vital knowledge and its explicit processes, such as create, collect, organize, distribute, apply, and exploit of knowledge to improve the organizational performance (Skyrme, 2003; [18]. KM is embedded four components of leadership, management, organization, technology, and learning [36]. Forcadell et al. introduced KM cycle including create, storage, distribute and use of knowledge to implement the KM strategies [11][31]. The implementation of $\mathrm{KM}$ requires the infrastructure that includes the knowledge processes, IT and organizational culture (Figure 1). This infrastructure indicates the enlargement of dimensions that KM implementation encompasses. Hence, successful implementation of KM depends on various factors, including: development of suitable infrastructure, incorporate KMS to organizational processes and information systems (IS); organizational structure; organizational culture; senior management support; staff training, maintaining the institutional memory; creating a $\mathrm{KM}$ strategy; KMS security; and creating motivation and commitment through the use of KM in the evaluation process [19].

The evaluation and development of readiness for implementation of the KMS, which includes both soft aspects of process and culture, and hard aspects of technology and software systems, are recommended to increase the success rates. Organizational readiness for KM implementation guarantees the organizational readiness to accept the philosophy of knowledge life cycle as a critical way of life [30]. 


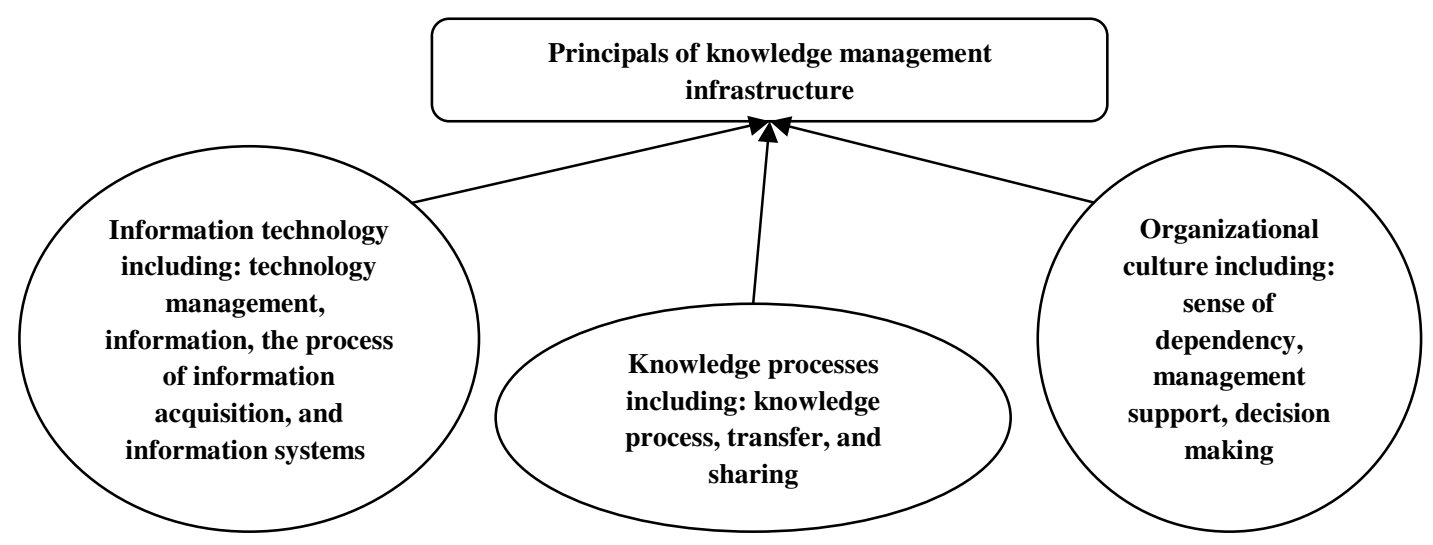

Figure.1. Principals of knowledge management infrastructure [31]

Organizational readiness for KM means the readiness to identify, collect, organize, store, distribute, and share of knowledge, and the capability to adopt and use of advantages [26]. Based on the literature review, the word "readiness" is used as the requisite for people or organization to successfully change [14] Research on organizational readiness for KM helps organizations to assess their readiness for knowledge sharing before the KM implementation [30]. According to previous studies, organizational readiness includes different cultural, structural, and technological aspects, such as individuals, the context, content and process of change, the tendency to knowledge management, confidence, and culture [6][12][15].

Mohanty \& Chand have proposed the extended maturity model of KM as the 5iKM3 that includes three key factors of individuals including culture, as well as the process including strategy and security policy, and IT including necessary infrastructure. The 5iKM3 are 5 levels of maturity model that includes primary level, plan, initiative, intelligence, and innovation [23]. Moreover, Khatibian et al., developed a model with 5 levels of initial, managed, defined, quantitatively management and optimizing that includes eight key factors (i.e., strategy, human resources, organizational structure, processes, culture, leadership, evaluation, and IT) and 42 factors influencing the successful administration of KM. Beside the mentioned factors many factors play important roles on KM implementation [21]; different studies used different terms to describe these factors that some of them are listed in table 1. 
International Journal of Information Technology Convergence and Services (IJITCS) Vol.5, No.6, December 2015

Table1. Key previous studies on the readiness for the implementation of knowledge management

\begin{tabular}{|c|c|c|}
\hline Source & Target & Factors \\
\hline [39] & $\begin{array}{l}\text { Investigating the factors affecting acceptance } \\
\text { management and extracting the main factors. }\end{array}$ & $\begin{array}{l}\text { Strategy, market benchmarking, knowledge structure, culture, } \\
\text { information technology, staff training, leadership and commitment, } \\
\text { teamwork and vocational training. }\end{array}$ \\
\hline [4] & $\begin{array}{l}\text { To study the factors affecting knowledge } \\
\text { management implementation based on enablers } \\
\text { and organizational processes. }\end{array}$ & $\begin{array}{l}\text { Cooperation; trust; education; centrality; } \\
\text { education; T-Shaped skills; IT supports }\end{array}$ \\
\hline$[30]$ & $\begin{array}{l}\text { To study the tactical and strategic factors of } \\
\text { knowledge and to propose a framework for } \\
\text { organizational readiness for knowledge } \\
\text { management }\end{array}$ & $\begin{array}{l}\text { Review reward policy; build trust through leadership; establish } \\
\text { personal metrics for knowledge sharing; establish ownership of } \\
\text { knowledge; create generic processes and procedures; move to } \\
\text { activity based costing; identify security policies; populate } \\
\text { knowledge evangelist role; create stretching process; identify } \\
\text { communities for knowledge; amend project reviews to ensure } \\
\text { discussion and capture of knowledge; create dynamic knowledge } \\
\text { and skills database; amend infrastructures, processes, procedures to } \\
\text { permit easy publication, searching, access; use knowledge-enabled } \\
\text { processes and procedures; amend and use personal appraisal } \\
\text { procedures to evaluate performance on knowledge management. }\end{array}$ \\
\hline$[31]$ & $\begin{array}{l}\text { To propose a unified analytic framework for } \\
\text { KM }\end{array}$ & Culture, technology, knowledge processes \\
\hline [23] & $\begin{array}{l}\text { To study the ability to adopt knowledge } \\
\text { management based on 5iKM3 maturity model }\end{array}$ & $\begin{array}{l}\text { People, culture, and process, strategy, security and IT policies and } \\
\text { necessary infrastructure }\end{array}$ \\
\hline$[17]$ & $\begin{array}{l}\text { To propose a conceptual model that can be used } \\
\text { to assess the organizational readiness and its } \\
\text { contributing factors for KM process adoption }\end{array}$ & Organizational structure, IT infrastructure, organizational culture \\
\hline [5] & To study the KM strategy and process & $\begin{array}{l}\text { Business strategy, organizational structure, knowledge management } \\
\text { team, technology, culture, leadership, Knowledge Evaluator, } \\
\text { knowledge map, construction, measurement, visualization, and } \\
\text { development. }\end{array}$ \\
\hline [33] & $\begin{array}{l}\text { To propose a model for investigating the effects } \\
\text { of cultural factors on the readiness for KM }\end{array}$ & $\begin{array}{l}\text { Trust, teamwork, Trust, teamwork, curiosity, optimism and positive } \\
\text { emotion, reward, and recognition system }\end{array}$ \\
\hline [26] & $\begin{array}{l}\text { To assess the organizational readiness for } \\
\text { knowledge management }\end{array}$ & IT infrastructure, processes, organizational culture \\
\hline$[35]$ & $\begin{array}{l}\text { To study the readiness for implementation of the } \\
\text { knowledge management }\end{array}$ & Change the content, process, context, people \\
\hline$[34]$ & $\begin{array}{l}\text { To investigate the knowledge sharing and to } \\
\text { identify factors that influence the readiness of } \\
\text { an organization to share knowledge effectively }\end{array}$ & $\begin{array}{l}\text { Learning from failures, data quality, performance orientation, } \\
\text { processes, infrastructures, the strategy of implementation, } \\
\text { organizational climate, the satisfaction of the change, open } \\
\text { atmosphere, leadership. }\end{array}$ \\
\hline [15] & $\begin{array}{|lccr|}\begin{array}{l}\text { To measure } \\
\text { management }\end{array} & \text { readiness for knowledge } \\
\end{array}$ & $\begin{array}{l}\begin{array}{l}\text { Individual, context, content, process, knowledge management } \\
\text { approach }\end{array} \\
\end{array}$ \\
\hline [29] & $\begin{array}{l}\text { To propose a model to assess the organizational } \\
\text { readiness for KM adoption }\end{array}$ & $\begin{array}{l}\text { People, systems, organization, technology, readiness levels, the } \\
\text { process of knowledge production }\end{array}$ \\
\hline$[24]$ & To study the Success Factors in KM readiness & $\begin{array}{l}\text { Culture, management, strategy, systems and infrastructure, effective } \\
\text { and systematic processes, measurement }\end{array}$ \\
\hline$[21]$ & $\begin{array}{l}\text { Measurement of knowledge management } \\
\text { maturity level within organizations }\end{array}$ & $\begin{array}{l}\text { Strategy, human resource, organizational structure, process, culture, } \\
\text { leadership, information technology, evaluation }\end{array}$ \\
\hline
\end{tabular}


The Models studied above, used similar components, and most of them have tried to extract the factors that influence the implementation of the KM and aim to improve its success rate. Some research also assessed their organizational readiness for $\mathrm{KM}$ implementation. The point is to identify the appropriate models for assessing the readiness of the organization for preimplementation, and to determine whether each of the models can be used in all organizations. Hence, the purpose of this study is to evaluate the combined model in three organizations that is described in detail in the next section.

\section{RESEARCH MODEL AND HYPOTHESES}

The theoretical basis of this study is to evaluate the readiness of the organizations for KM implementation. Based on the conceptual study and literature review, two basic models of Mohanty and Chand and Khatibian et al., has been developed [23][21]. The conceptual model of the study contains organizational culture, knowledge processes, IT infrastructure [24][21][23][26], individuals, strategy [24] [21][35], senior management commitment [21][24], which is illustrated in Figure 1, and associated hypotheses are explained as follows:

\section{- Organizational Culture}

According to Davenport and Prusak, organizational culture is the most important component of the $\mathrm{KM}$ implementation, and business culture is an organizational determinant factor of $\mathrm{KM}$ initiatives [8]. The studies of Taylor et al. showed the positive relationship between culture and the implementation of KM in the organization [34]. Therefore, the hypothesis 1 is explained as follows:

Hypothesis 1: organizational culture is effective on the organization's readiness for $\mathrm{KM}$ implementation.

\section{- Individuals}

Individuals' skills, roles, knowledge, motive, reinforcement, learning, social networks, contacts, coordination, and creativity are effective on the KM implementation [25]. Khatibian et al. showed that individuals play the significant role in the success of the implementation [21]. Therefore, the hypothesis 2 is explained as follows:

Hypothesis 2: Individuals are effective on the organizational readiness for KM implementation.

\section{- Knowledge Processes}

$\mathrm{KM}$ processes include the processes of collect and organize, apply and protect the knowledge asset. Khatibian et al. and Mohammadi et al. ascertained the direct effects of knowledge processes on the successful implementation of KM [26][21]. Therefore, the hypothesis 3 is explained as follows:

Hypothesis 3: knowledge processes are effective on the organization's readiness for KM implementation. 


\section{- Senior Management Commitment}

Senior managers are responsible for providing insight, information, Consultation, leadership, supervision, coaching, and supporting, that are essential for appropriate KM. the ongoing strategic commitment of senior management to KM is being known as the success factor of KM programs. Wong, Matti, and Holt et al. studies indicated the positive relationship between senior management commitment and KM implementation [37][15][24]. Therefore, hypothesis 4 is explained as follows:

Hypothesis 4: Senior management commitment is effective on the organization's readiness for KM implementation.

\section{- IT Infrastructure}

Alavi \& Leidner integrated IT and knowledge management to facilitate the distribution of structured knowledge and make the use and search of knowledge easier [2]. Mati, Hassanali and Jafari et al. found a positive relationship between IT infrastructure and KM [13][16][24]. Therefore, Hypothesis 5 is explained as follows:

Hypothesis 5: IT infrastructure is effective on the organization's readiness for KM implementation.

\section{- Organizational Strategy}

The strategic direction of the organization and knowledge strategies provide a suitable framework for organizational readiness to adopt KM [5]. Khatibian et al., and Matti found a positive relationship between organizational strategy and KM [21][24]. Therefore, Hypothesis 6 is explained as follows:

Hypothesis 6: organizational strategy is effective on the organization's readiness for KM implementatio

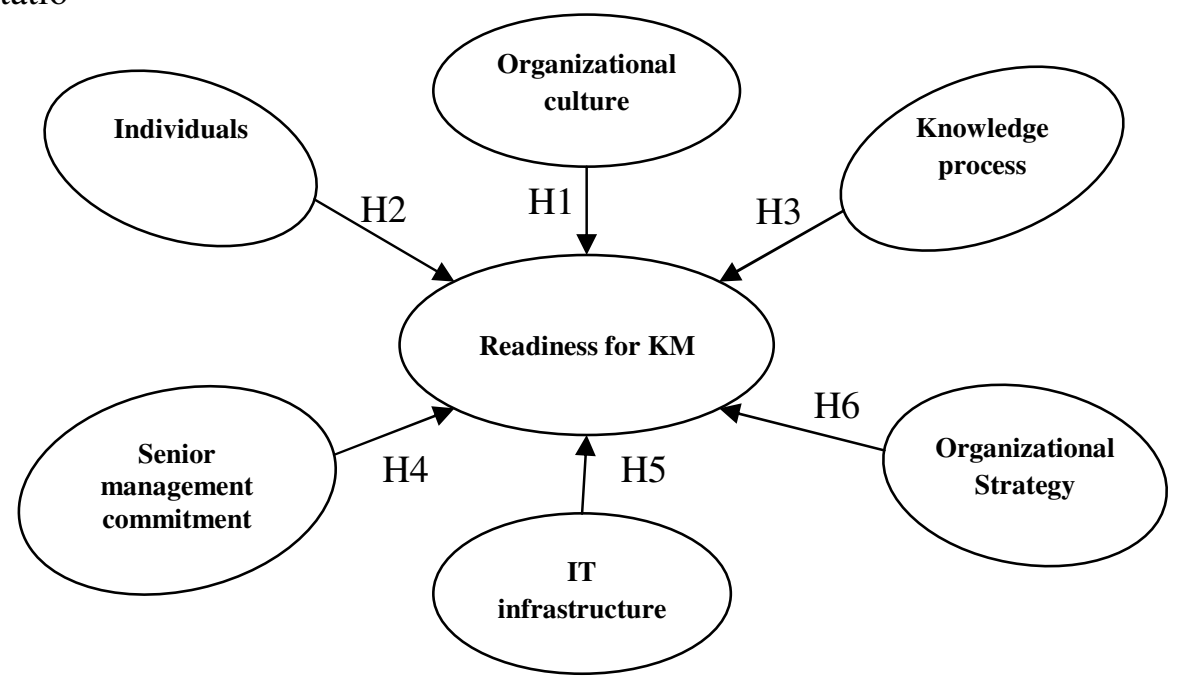

Fig 1. Research Model 


\section{Method: Participants And Data Collection}

The purpose of this study is to assess the organizational readiness for KM implementation. The data-gathering instrument was a questionnaire that designed based on the literature review on key factors of organizational readiness. Table 2 indicates the factors and their sources. The reliability and validity of the questionnaire were examined using experts' ideas [24][15][21] [26] and Cranach's alpha, which was 0.89 for the whole scale of the questionnaire. The participants of the study were 118 managers and knowledge workers of three different organizations of commerce (53 respondents), educational (20 respondents) and IT service (43 respondents) that have not yet implemented KM systems. Based on the results, $42.2 \%$ of the respondents were men and $56.8 \%$ were women; furthermore 55\% of respondent had BA degree (the highest), and 5.9\% had P.H.D (the lowest). Moreover, 56\% of respondent were the employee and 5\% were the lecturer; also $10 \%$ of them had worked experience of more than 10 years.

The partial least squares (PLS) method was used for analyzing the measurement and validity of the questionnaire and to analyze the model. This method provides the chance to perform both principal component and path analysis simultaneously [38].

\subsection{Data Analysis}

The adequacy of the measurement model was determined using factor loading coefficient, composite reliability, and AVE. According to Amani et al., the AVE higher than 0.5, the composite reliability higher than 0.7 and communality higher than 0.6 is acceptable that based on the results the model is confirmed (see Table 2) [3]. As Table 2 indicates the measures are robust in terms of their internal consistency reliability as indexed by the composite reliability. Moreover, the hypotheses were tested by assessing the structural model; this involved estimating the path coefficients and the R2 value. The bootstrap resampling method of PLS was used to determine the significance of the path coefficients. According to Chin (1998), R2 higher than 0.67 is strong, higher than 0.33 is mediated and 0.19 is weak. About the results, our model is in the mediated level.

Table. 3 indicates the Conformity factor analysis. According to the results, the loading of 1 index (Strategy) and eight factors (i.e., innovation, learning, cooperation, suitable environment, management support, readiness for KM, satisfaction, and changes) were less than 0.5 and were dropped from further analysis.

Table 2. Model Analysis

\begin{tabular}{|c|c|c|c|c|c|c|}
\hline & $\begin{array}{c}\text { Std } \\
\text { deviatio } \\
\mathbf{n}\end{array}$ & $\begin{array}{c}\text { Composit } \\
\mathbf{e} \\
\text { reliability }\end{array}$ & $\mathbf{R}^{\mathbf{2}}$ & $\begin{array}{c}\text { Cronbach' } \\
\text { S alpha }\end{array}$ & $\begin{array}{c}\text { Communalitie } \\
\mathbf{S}\end{array}$ & Source \\
\hline $\begin{array}{c}\text { Organization } \\
\text { al culture }\end{array}$ & 0.675782 & 0.895295 & & 0.856168 & 0.6757582 & {$[26][21][24]$} \\
\hline Individual & 0.766935 & 0.850017 & & 0.781183 & 0.766935 & {$[21][12][35]$} \\
\hline $\begin{array}{c}\text { IT } \\
\text { infrastructur } \\
\mathbf{e}\end{array}$ & 0.770932 & 0.909737 & & 0.853049 & 0.770932 & {$[23][24][26]$} \\
\hline $\begin{array}{c}\text { readiness for } \\
\text { knowledge }\end{array}$ & 1.000000 & 1.000000 & $\begin{array}{c}0.37080 \\
0\end{array}$ & 1.000000 & 1.000000 & \\
\hline
\end{tabular}


International Journal of Information Technology Convergence and Services (IJITCS) Vol.5, No.6, December 2015

\begin{tabular}{|c|c|c|c|c|c|c|}
\hline management & & & & & \\
\hline $\begin{array}{c}\text { Senior } \\
\text { management } \\
\text { commitment }\end{array}$ & 0.732453 & 0.861048 & & 0.773683 & 0.732453 & {$[24][21]$} \\
\hline $\begin{array}{c}\text { Knowledge } \\
\text { processes }\end{array}$ & 0.697095 & 0.816120 & & 0.757528 & 0.697095 & {$[35][26][23]$} \\
\hline
\end{tabular}

Table 3. Loading Factors

\begin{tabular}{|c|c|c|c|c|c|c|c|}
\hline & $\begin{array}{l}\text { 1- } \\
\text { Organization } \\
\text { al culture }\end{array}$ & $\begin{array}{l}\text { 2- } \\
\text { Individuals }\end{array}$ & $\begin{array}{l}\text { 3-IT } \\
\text { infrastructure }\end{array}$ & $\begin{array}{l}\text { 4-Senior } \\
\text { managemen } \\
\mathrm{t} \\
\text { commitment }\end{array}$ & $\begin{array}{l}5- \\
\text { Knowledge } \\
\text { process }\end{array}$ & $\begin{array}{l}6- \\
\text { strategy }\end{array}$ & $\begin{array}{l}\text {-KM } \\
\text { readines } \\
\mathrm{s}\end{array}$ \\
\hline $\begin{array}{l}\text { 1-1 Learning } \\
\text { of failure }\end{array}$ & 0.726547 & 0.421031 & 0.522870 & 0.098960 & 0.295600 & -0.296725 & 0.115375 \\
\hline 1-2 honesty & 0.952852 & 0.522092 & 0.525175 & -0.070942 & 0.456186 & 0.371327 & 0.260713 \\
\hline 1-3 learning & 0.024515 & 0.036240 & 0.026546 & -0.055749 & 0.050582 & 0.025644 & 0.011367 \\
\hline $\begin{array}{l}1-4 \\
\text { cooperation }\end{array}$ & 0.281477 & 0.008515 & 0.014460 & 0.004435 & 0.006045 & 0.076539 & 0.029438 \\
\hline $\begin{array}{l}1-5 \text { suitable } \\
\text { environment }\end{array}$ & 0.027569 & 0.019068 & -0.217707 & 0.024178 & 0.001553 & -0.013162 & 0.009012 \\
\hline $\begin{array}{l}2-1 \\
\text { commitment }\end{array}$ & 0.558019 & 0.668179 & 0.250993 & 0.137704 & 0.216414 & 0.133848 & 0.082339 \\
\hline $\begin{array}{l}2-2 \\
\text { knowledge }\end{array}$ & 0.472074 & 0.889619 & 0.374372 & -0.031991 & 0.264840 & 0.261856 & 0.174816 \\
\hline $\begin{array}{l}2-3 \\
\text { satisfaction }\end{array}$ & -0.038617 & 0.031155 & 0.029003 & -0.050877 & 0.075752 & 0.086333 & 0.006436 \\
\hline 2-4 changes & 0.013341 & 0.291894 & 0.025044 & -0.024696 & 0.011655 & -0.025430 & 0.082242 \\
\hline $\begin{array}{l}\text { 3-1 } \\
\text { Information } \\
\text { quality } \\
\end{array}$ & 0.489267 & 0.257375 & 0.929236 & -0.178819 & 0.435075 & 0.279773 & 0.411627 \\
\hline $\begin{array}{l}\text { 3-2 } \\
\text { Infrastructur } \\
\text { e capacity }\end{array}$ & 0.469800 & 0.326994 & 0.853733 & -0.107806 & 0.339754 & 0.275195 & 0.288477 \\
\hline $\begin{array}{l}\text { 3-3 Efficient } \\
\text { security } \\
\text { policies }\end{array}$ & 0.588858 & 0.392047 & 0.848796 & -0.148866 & 0.371158 & -0.314821 & 0.274455 \\
\hline $\begin{array}{l}4-1 \mathrm{KM} \\
\text { readiness }\end{array}$ & 0.006083 & 0.178799 & 0.122381 & -0.288822 & 0.062176 & 0.059959 & 0.131562 \\
\hline $\begin{array}{l}5-1 \\
\text { Management } \\
\text { support }\end{array}$ & 0.029352 & 0.042679 & -0.097035 & -0.072795 & 0.011897 & -0.070716 & 0.120699 \\
\hline $\begin{array}{l}\text { 5-2 Resource } \\
\text { allocation }\end{array}$ & -0.037010 & 0.023324 & -0.107248 & 0.663108 & -0.066328 & 0.021020 & 0.120780 \\
\hline 5-3 strategy & 0.012288 & 0.015804 & -0.077476 & 0.650007 & -0.056411 & 0.002687 & 0.118722 \\
\hline $\begin{array}{l}6-1 \\
\text { appropriate } \\
\text { strategy }\end{array}$ & 0.042679 & 0.097035 & 0.120699 & 0.707916 & 0.011897 & -0.081970 & 0.072795 \\
\hline
\end{tabular}


International Journal of Information Technology Convergence and Services (IJITCS) Vol.5, No.6, December 2015

\begin{tabular}{|l|l|l|l|l|l|l|l|}
\hline & $\begin{array}{l}\text { 1- } \\
\text { Organization } \\
\text { al culture }\end{array}$ & $\begin{array}{l}\text { 2- } \\
\text { Individuals }\end{array}$ & $\begin{array}{l}\text { 3-IT } \\
\text { infrastructure }\end{array}$ & $\begin{array}{l}\text { 4-Senior } \\
\text { managemen } \\
\text { t } \\
\text { commitment }\end{array}$ & $\begin{array}{l}\text { 5- } \\
\text { Knowledge } \\
\text { process }\end{array}$ & $\begin{array}{l}\mathbf{6 -} \\
\text { strategy } \\
\text { readines } \\
\text { S }\end{array}$ \\
\hline $\begin{array}{l}\text { 6-2 } \\
\text { Innovative } \\
\text { Strategy }\end{array}$ & 0.275689 & 0.190698 & 0.217707 & 0.024178 & $\mathbf{0 . 5 9 6 4 3 6}$ & 0.333791 & 0.326994 \\
\hline $\begin{array}{l}\text { 7-1 Process } \\
\text { of knowledge } \\
\text { creation }\end{array}$ & 0.468487 & 0.268901 & 0.449209 & -0.124448 & $\mathbf{0 . 9 2 9 5 0 4}$ & -0.065781 & 0.342428 \\
\hline $\begin{array}{l}\text { 7-2Reward } \\
\text { system }\end{array}$ & 0.243834 & 0.188059 & 0.380605 & -0.184891 & 0.373881 & -0.171596 & $\mathbf{1 . 0 0 0 0 0 0}$ \\
\hline \multicolumn{2}{|l|}{ Notes: The loadings of highlighted factors were not confirmed and were eliminated. } & & \\
\hline
\end{tabular}

The result of the structural model assessment is presented in Fig. 3. Based on the results the fit of the overall model was acceptable. As presented in Fig. 3, the effect of culture was rejected on the three organization's readiness for KM implementation. Thus, Hypotheses1 was rejected in three organizations. Based on the results, IT infrastructure had positive effect on the educational (path coefficient $=0.350, p<0.01$ ), commerce (path coefficient $=0.372, p<0.05$ ) organizations, and its effect was confirmed in IT organization's (path coefficient $=-0.411, \mathrm{p}<0.05$ ) readiness for KM implementation. Thus, the Hypotheses 5 was supported. Moreover, senior management commitment (path coefficient $=-0.291, \mathrm{p}<0.05$ ) was effective on the IT organization's readiness for KM implementation. Thus, Hypotheses 4 was supported in IT organization. Furthermore, the results indicated that individual (path coefficient $=0.041, \mathrm{p}<0.05$ ) has a positive effect on educational organization's readiness for KM implementation, therefore the Hypotheses 2 was supported in an educational organization. The results of commerce organizations indicated that Knowledge processes (path coefficient $=0.328, \mathrm{p}<0.05$ ) were effective on the readiness for KM implementation and supported the Hypotheses 3 in commerce organizations. The results of hypothesis tests are presented in Table 4.

Table 4. Tests of hypotheses

\begin{tabular}{|c|c|c|c|c|c|c|c|c|c|}
\hline \multirow[t]{2}{*}{ Hypothesis } & \multicolumn{3}{|c|}{ Educational } & \multicolumn{3}{|c|}{ Commerce } & \multicolumn{3}{|c|}{ IT } \\
\hline & $\begin{array}{c}\text { Path } \\
\text { Coefficient }\end{array}$ & T value & $P$ value & $\begin{array}{c}\text { Path } \\
\text { Coefficient }\end{array}$ & T value & $P$ value & $\begin{array}{c}\text { Path } \\
\text { Coefficient }\end{array}$ & T value & $\begin{array}{c}\mathbf{P} \\
\text { value }\end{array}$ \\
\hline H1 & $-0.092 x$ & $0.980^{\times}$ & $0.382^{\times}$ & $-0.043 x$ & $0.407^{\times}$ & $0.704^{\times}$ & $-0.001 \times$ & $0.010 x$ & $0.992^{\times}$ \\
\hline $\mathrm{H} 2$ & $0.041^{*}$ & $0.425^{\times}$ & $0.011^{*}$ & $0.220 \times$ & $2.266^{*}$ & $0.086^{\times}$ & $0.389 x$ & $1.602^{x}$ & $0.184^{\times}$ \\
\hline H3 & $0.151 \times$ & $1.204^{\times}$ & $0.294^{\times}$ & $0.328 *$ & $3.189 *$ & $0.033 *$ & $0.160 \times$ & $1.708^{\times}$ & $0.162^{x}$ \\
\hline $\mathrm{H} 4$ & $0.219^{\times}$ & $2.002 *$ & $0.115^{\times}$ & $-0.178 x$ & $1.356^{\times}$ & $0.123^{\times}$ & $-0.291 *$ & $2.754 *$ & $\begin{array}{c}0.049 \\
*\end{array}$ \\
\hline H5 & $0.350 * *$ & $4.373 *$ & $0.005^{* *}$ & $0.372 *$ & $3.701 *$ & $0.010 *$ & $-0.411 *$ & $2.295^{*}$ & $0.041^{*}$ \\
\hline $\begin{aligned} \text { Note 1: } & \mathrm{P}<0.0 \\
& \mathrm{P}<0.0 \\
& \text { Rejec }\end{aligned}$ & $\begin{array}{l}* \\
* \\
\times\end{array}$ & Note2: $\mathrm{T}$ & $1.96 *$ & & & & & & \\
\hline
\end{tabular}




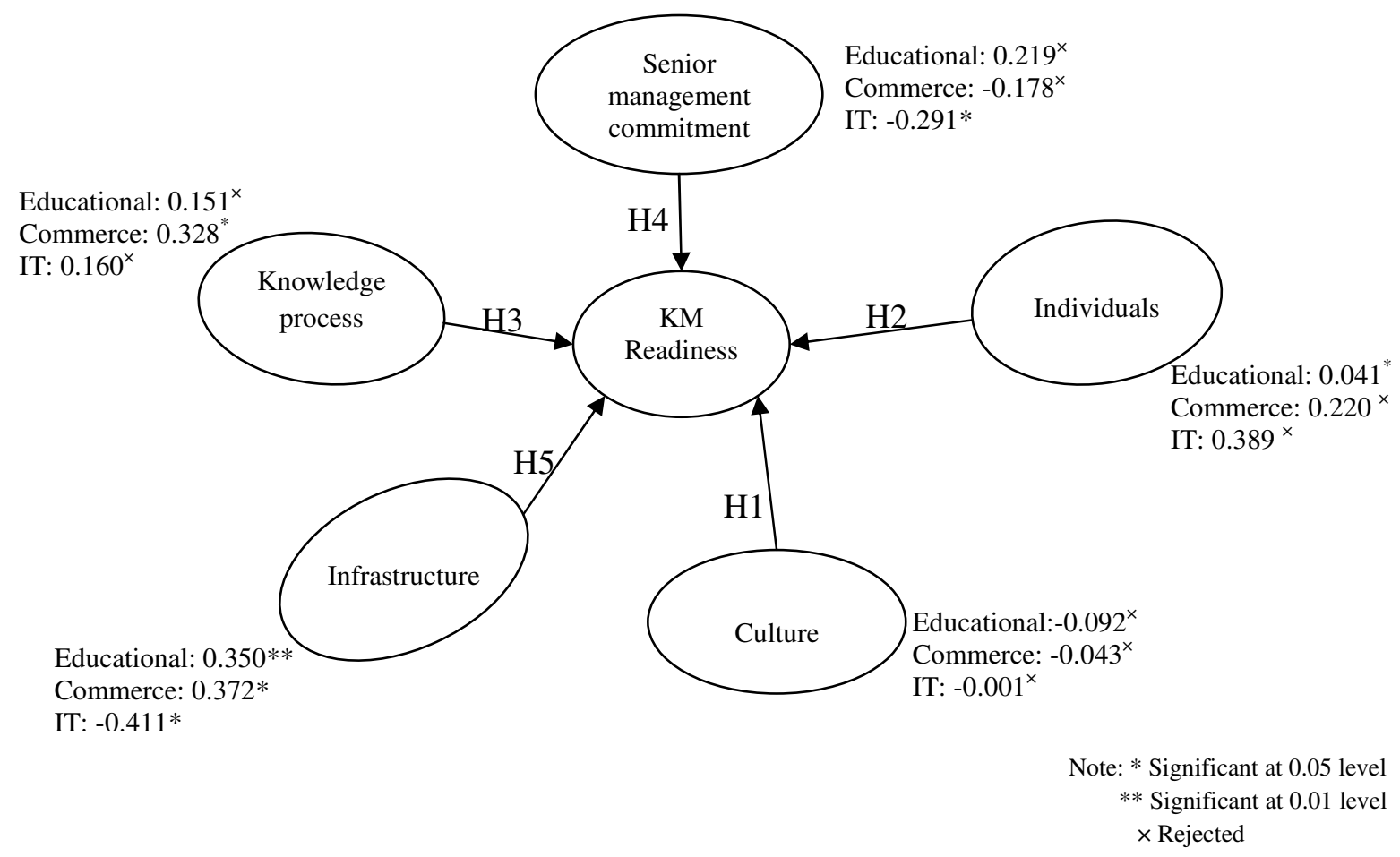

Fig 3. Result of Structural Model Test

\section{CONCLUSION AND RECOMMENDATIONS}

Knowledge management as a systematic and organized mechanism can lead organizations to the optimal use of knowledge. When organizations are increasingly aware of the consequences of KM use, its necessity will become clear. Hence, this study examined the organization's readiness for $\mathrm{KM}$ implementation in three organizations of IT services, educational and commerce.

The objective of this study was to run a specific model in various organizations to investigate whether a general model of readiness is applicable is all organizations. Hence, factors affecting organization's readiness for KM implementation were extracted and were classified in six groups of organizational culture, individual, IT infrastructure, knowledge process, strategy, and senior management commitment. After gathering data from three studied organizations (i.e., IT services, commerce and educational), the structural equation modeling was used for the analysis.

The result of the structural model assessment indicated that the fit of the overall model was acceptable. According to the results, the effect of culture was rejected in three studied organizations that is inconsistent with those of Siemieniuch \& Sinclair, Khatibian et al., Mohammadi et al., Sivan, and Mathi that emphasized the effect of culture on organization's readiness for KM implementation [31] [30][26][24][21]. Moreover the results confirmed the effect of IT infrastructure on three studied organization's readiness, that is consistent with the findings of Quin et al., Jalaledeen et al., (2009), Mohammadi et al., and Khatibian et al. that IT 
infrastructure is effective on every three studied organization's readiness for KM implementation [29][26][21]. According to the results, IT infrastructure had negative effect on IT organization that indicates IT organization does not have the suitable IT infrastructure for KM implementation. Hence, it is suggested that organizations promote employees technical skills in the use of IS, and make them more familiar with IS usage and advantages through the classes, workshops, and seminars.

Considering the importance of senior management commitment in different studies, the effect of senior management commitment was examined in this study and similar to the findings of Siemieniuch \& Sinclair, Quin et al., in multi-sectors and Yu-Chung et al. in the pharmaceutical industry, the result of this study confirmed the negative effects of senior management commitment on the IT organization's readiness for KM implementation [39][29][30]. In this regard, the effective relationship between managers and employees, and the support of senior managers are the issue that must be considered in IT organizations.

Moreover, similar to the studies of Khatibian et al., Mohammadi et al., Sivan in multi-sectors [31][26][21] and Mathi in commerce organizations [24], the effect of knowledge process on the organization's readiness for KM implementation were confirmed in commerce organization, its effect was rejected in IT and educational organizations. According to the Sivan lack of documented processes and procedures to access the required knowledge as well as the lack of knowledge workers among various units will cause this result [31]. Hence, the creation of knowledge management unit, the conduct of regular business processes, and codification of knowledge rules and regulations is recommended.

With regard to the focus of different studies such as Quin et al., in public sectors [29], Shaw et al., in IT and research organizations [33], and Holt et al. in multi-sectors on the individual as effective factors of organization's readiness for KM implementation [15], this study examined the effect of this factor, and the results supported the effect of individual on the educational organizations readiness, but its effect was rejected in IT and commerce organizations. Hence, organizations should hire expert employees and create the suitable basis for continuous learning, create the suitable environment for participation, and provide the mutual trust between the employees to make them ready for KM implementation.

According to the results, the different hypothesis has been confirmed in different organizations. Hence, based on the organization's scope different factors must be applied to prepare the organization for KM implementation. Therefore, it is suggested that organizations provide suitable frameworks to extract required models rather than providing the evaluation models.

This research was conducted in three different organizations of IT services, educational and commerce that the low number of population is one of the limitations of this study, therefore it is better to investigate the research model in different organizations and industrial sectors. Moreover, it is possible to obtain different models for different sectors through the extensive research. Hence, more researches are necessary to determine whether the industry caused the differences among effective factors on the organization's readiness or other factors are also effective. 


\section{REFERENCES}

[1] Alavi, Maryam., \& Leidner, Dorothy E. (1999). "Knowledge management systems: issues, challenges, and benefits". Communications of the AIS, 1(2es), p.1.

[2] Alavi, Maryam, \& Leidner, Dorothy E. (2001). "Review: Knowledge management and knowledge management systems: Conceptual foundations and research issues". MIS quarterly, pp.107-136.

[3] Amani, Javad., et al. (2012). "An Introduction of Structural Equations Modeling by PLS Method and its Application in Behavioral Sciences". Oroumieh University Publication, pp.126-139.

[4] Chang Lee, Kun., Lee, Sangjae., \& Kang, InWon (2005). "KMPI: measuring knowledge management performance". Information \& Management, 42(3), pp.469-482. doi: http:..dx.doi.org.10.16.j.im.2004.02.003

[5] Chin Wei, Chong, Chong Siong Choy, and Wong Kuan Yew. (2009). "Is the Malaysian telecommunication industry ready for knowledge management implementation?". Journal of knowledge management, 13(1), pp. 69-87.

[6] Choi, Byounggu., \& Lee, Heesseok (2002). "Knowledge management strategy and its link to knowledge creation process". Expert Systems with applications, 23(3), pp.173-187.

[7] Davenport, Thomas H., \& Prusak, Laurence (1998). Working knowledge: How organizations manage what they know: Harvard Business Press.

[8] Davenport, Thomas H., \& Prusak, Laurence (2000). "Working Knowledge-How Organizations Manage What They Know". Harvard Business School Press, Boston, MA.

[9] Drucker, Peter (1999). "Knowledge-worker productivity: The biggest challenge". The knowledge management yearbook 2000-2001.

[10] El-Mekawy, Mohammed, \& Rusu, Lazar (2011, 4-7 Jan. 2011). Organizational Culture Impact on Business-IT Alignment: A Case Study of a Multinational Organization. Paper presented at the 44th Hawaii International Conference on System Sciences (HICSS).

[11] Forcadell, Francisco J., \& Guadamillas, Fatima (2002). "A case study on the implementation of a knowledge management strategy oriented to innovation". Knowledge and Process Management, 9(3), pp.162-171.

[12] Gold, Andrew H., Malhotra, Arvind \& Segars, Albert (2001). "Knowledge management: an organizational capabilities perspective". J. of Management Information Systems, 18(1), pp.185-214.

[13] Hasanali, Farida (2002). "Critical success factors of knowledge management". Knowledge Management Advantage.

[14] Holt, Daniel (2000). The measurement of readiness for change: A review of instruments and suggestions for future research. Paper presented at the annual meeting of the academy of management, Toronto, Canada.

[15] Holt, Daniel , Armenakis, Achilles , Feild, Hubert S., \& Harris, Stanley G. (2007). "Readiness for Organizational Change The Systematic Development of a Scale". The Journal of applied behavioral science, 43(2), pp.232-255.

[16] Jafari, Mostafa, Fathian, Mohammad, Jahani, Alireza, \& Akhavan, Peyman (2008). "Exploring the contextual dimensions of the organization from knowledge management perspective". VINE, 38(1), pp.53-71.

[17] Jalaldeen, Mohammed, Razi, Mohammed,Abdul Karim Shariza, Nor \& Mohamed, Norshidah (2009). "Organizational readiness and its contributing factors to adopt km processes: A conceptual model". Communications of the IBIMA, 8(17), pp.128-136.

[18] Jashapara, Ashok (2004). Knowledge management: an integrated approach. Harlow: Financial Times Prentice Hall.

[19] Jennex, Murray, \& Olfman, Lorne (2005). "Assessing knowledge management success". International Journal of Knowledge Management (IJKM), 1(2), pp.33-49.

[20] Leidner, Dorothy E. (2010). "Globalization, Culture, and Information: Towards Global Knowledge Transparency". The Journal of Strategic Information Systems, 19, pp.69-77. 
[21] Khatibian, Neda., Gholori pour,Tahmoores Hassan \& Abedi jafari, Hassan (2010). "Measurement of knowledge management maturity level within organizations". Business Strategy Series, 11(1), pp.5470. doi: doi:10.1108.17515631011013113

[22] Kamal, Muhammad mostafa \& Petree, Russel (2011). Enterprise IT Asset Management. Review of Business Information Systems (RBIS), 10(3), 47-52.

[23] Mohanty, S. \& Chand, M. (2004). "5iKM3 knowledge management maturity model for assessing and harnessing the organizational ability to manage knowledge". TATA Consultancy Services.

[24] Mathi, Kavindra (2004). "Key success factors for knowledge management". University of Applied Sciences, Offenburg, thesis, Master of Business Administration in International Business Management and Consulting.

[25] Moffett, Sandra, Rodney McAdam, and Stephen Parkinson (2003). "An empirical analysis of knowledge management applications". Journal of knowledge Management, 7(3), pp.6-26.

[26] Mohammadi, Kaveh., Khanlari,Amir., \& Sohrabi,Babak. (2010). "Organizational readiness assessment for knowledge management". Information Resources Management: Concepts, Methodologies, Tools, and Applications, 279.

[27] Nonaka, Ikuijiro \& Takeuchi, Hirutaka (1995). The knowledge-creating company: How Japanese companies create the dynamics of innovation: Oxford university press.

[28] Nonaka, Ikuijiro \& Takeuchi, Hirotaka (1997). "The knowledge-creating company". 1995.

[29] Quin, T. Y., Hamdan, A.R , Mohammed Yusoff, C. (2007). "A Knowledge Management Readiness Model For The Public Sector". Proceedings of the International Conference on Electrical Engineering and Informatics Institut Teknologi Bandung, Indonesia, pp. 17-19.

[30] Siemieniuch, C. E., \& Sinclair, M. A. (2004). "A framework for organisational readiness for knowledge management". International Journal of Operations \& Production Management, 24(1), pp.79-98.

[31] Sivan, Yesha (2000). "Nine keys to a knowledge infrastructure: A proposed analytic framework for organizational knowledge management". In WebNet World Conference on the WWW and Internet, 2000(1), pp. 495-500.

[32] Spender, John Christopher. (1996). "Making knowledge the basis of a dynamic theory of the firm". Strategic management journal, 17, pp.45-62.

[33] Shaw, Nancy C., Mary J. Meixell, and Francis D. Tuggle (2003, January). "A case study of integrating knowledge management into the supply chain management process". In System Sciences, 2003. Proceedings of the 36th Annual Hawaii International Conference on (p. 10). IEEE.

[34] Taylor, W. Andrew \& Wright, Gillian H. (2004). "Organizational readiness for successful knowledge sharing: challenges for public sector managers". Information Resources Management Journal (IRMJ), 17(2), pp.22-37.

[35] Trent, Martin R. (2003). Assessing Organization Culture Readiness for Knowledge Management Implementation: The Case of Aeronautical Systems Center Directorate of Contracting: DTIC Document

[36] Watson, Ian (2003). Applying knowledge management: techniques for building corporate memories: Morgan Kaufmann.

[37] Wong, Kuan Yew (2005). "Critical success factors for implementing knowledge management in small and medium enterprises". Industrial Management \& Data Systems, 105(3), pp.261-279.

[38] Yeon Park. Joo, Shin I'm. Kun \& Kim. Joon. S (2011), "The role of IT human capability in the knowledge transfer process in IT outsourcing context", Information \& Management 48 (2011), pp. 53-61

[39] Yu-Chung, Hung, Huang, Shi-Ming, \& Lin, Que-Pin (2005). "Critical factors in adopting a knowledge management system for the pharmaceutical industry". Industrial Management \& Data Systems, 105(2), pp.164-183.

[40] Zack, Michel, McKeen, James, \& Singh, Satyendra (2009). "Knowledge management and organizational performance: an exploratory analysis". Journal of knowledge management, 13(6), pp.392-409. 